\title{
Wetland Ecosystem Response to Hydrologic Restoration and Management: The Everglades and its Urban- Agricultural Boundary (FL, USA)
}

\author{
Pamela L. Sullivan • Evelyn E. Gaiser • Donatto Surratt • \\ David T. Rudnick • Stephen E. Davis • Fred H. Sklar
}

Received: 20 November 2013 / Accepted: 20 February 2014/Published online: 11 April 2014

(C) Society of Wetland Scientists 2014

\begin{abstract}
Wetland restoration success depends on understanding ecohydrological complexities in addition to the historical extent and legacies of past modifications. Restoration effectiveness in the Florida Everglades has been studied for several decades. We focused this special issue on the effects of hydrologic restoration in the southeastern Everglades, as this region provides a model for understanding wetland and estuarine response to management and restoration along an urban-agricultural-wetland boundary. We synthesize several decades of interdisciplinary wetland ecosystem restoration studies examining the influence of hydrologic and biogeochemical changes on spatial and temporal patterns of ecosystem structure and function. Our goal is to improve restoration effectiveness by revealing connections between water management activities and ecosystem changes. Synthesis of these
\end{abstract}

\author{
P. L. Sullivan $(\bowtie)$ \\ Earth and Environmental Systems Institute, Pennsylvania State \\ University, University Park, PA 16802, USA \\ e-mail: pls21@psu.edu \\ E. E. Gaiser \\ Department of Biological Sciences and Southeastern Environmental \\ Research Center, Florida International University, Miami, \\ FL 33199, USA \\ D. Surratt \\ South Florida Natural Resources Center, National Park Service, \\ Boynton Beach, FL, USA

\section{T. Rudnick} \\ South Florida Natural Resources Center, Everglades National Park, \\ Homestead, FL 33030, USA \\ S. E. Davis \\ Everglades Foundation, Palmetto Bay, FL 33157, USA \\ F. H. Sklar \\ South Florida Water Management District, Everglades Systems \\ Assessment Section, West Palm Beach, FL 33406, USA
}

long-term data suggests restoration success is contingent on quantifying the influences hydrologic restoration on landscape connectivity within and outside of the Everglades boundaries, in addition to its interactions with organisms and their complex food webs. Rehabilitating habitat structure and connectivity in the southeastern Everglades can be accomplished through increasing delivery of clean freshwater to its primary flow-way, Taylor Slough. This compendium indicates that reversal of water quality impacts of rehydration is possible given timely and informed approaches that improve the flow clean freshwater to the Everglades.

Keywords Biogeochemical interactions · Oligotrophic . Aquatic consumers · Macroinvertebrates · Water quality · Vegetation response $\cdot$ Restoration $\cdot$ Sea-level rise

Wetland restoration is the process of assisting recovery of a wetland that has been degraded, damaged, or destroyed, which is often contingent upon recreating hydrologic conditions that mirror historic water flow, depths, timing and distribution (Zedler 2006). Restoring wetlands that are surrounded by urban and agricultural lands is extremely challenging as the water needs of the wetland and adjacent developed lands can conflict and often are in direct competition. Along many wetland-urban boundaries, efforts to improve wetland ecosystem function through hydrologic restoration can be complicated by the commensurate introduction of non-native species, nutrients and contaminants associated with adjacent commercial, residential and agricultural lands (Sklar et al. 2005; Cadenasso et al. 2008). With approximately $50 \%$ of the world's wetland cover lost and a large portion of remaining wetlands degraded, there are growing efforts to rehabilitate wetlands and their increasingly-recognized wealth of ecosystem services (Zedler 2006). Restoration approaches vary with the extent and legacies of historical modifications, as well as 
the ecosystem's underlying hydrological and ecological complexities. Therefore, successful restoration approaches are often linked to a clear understanding of the history and complexity of the system. Few restorative programs to date have the wealth of scientific data necessary for a fully informed design, and therefore must adapt to information in order to be successful. In this issue, we focus on the effects of a series of restoration projects that modified connectivity along the Everglades urban-agriculture-wetland boundary (Florida) in efforts to rehabilitate Everglades habitat while maintaining freshwater supply, flood control and other ecosystem services that matter to people. For several decades, restoration approaches in this notable wetland have been implemented, modified, and their effectiveness studied, providing an excellent platform for understanding wetland ecological response to hydrologic restoration.

Like many wetlands in the 20th century, canals, dikes, and levees were constructed across the Everglades to provide land for agricultural development and flood protection for a growing human population. Water diversion and resultant compartmentalization of this once vast "River of Grass" reduced the characteristic slow sheet-flow of water through marshes. These hydrologic modifications have also increased both inundation depths and duration within the impounded 'water conservation areas' used for flood control and water supply, while reducing depths at the southern extent and eastern boundary of Everglades National Park (ENP). The hydrologic degradation of the Everglades has been concomitant with the homogenization of the ecosystem (Larsen et al. 2007), loss of biodiversity (Lorenz 2014a), and landward migration of saltwater into the potable aquifer (Ross et al. 2000; Price et al. 2006). Restoring the hydrology of the Everglades to conditions that resemble the pre-drainage landscape, including water flow, depths, timing and distribution, is a goal of the Comprehensive Everglades Restoration Plan (CERP; www. evergladesplan.org). The success of CERP is envisioned as the recovery and sustenance of the Everglades' defining characteristics, which includes its oligotrophic nature, a broad and connected landscape of plant communities with abundant wildlife, and productive estuaries (Fig. 1). One of CERP's greatest restoration challenges is the achievement of hydrologic improvements while concurrently maintaining or restoring the system's oligotrophic nature, which is largely a function of low phosphorus availability to primary producers. This challenge of restoring water quantity while protecting water quality and natural features is not unique to the Everglades wetland system (Palmer et al. 2005). Therefore, a coordinated analysis and interpretation of regional data and scientific discoveries is a worthy effort, as it will inform wetland restoration decisions worldwide.

Within ENP, restoration plans include a several-stage process of improving the hydrologic patterns in the two major flow-ways, the Shark River Slough and Taylor Slough, and discharge to their downstream estuaries. Taylor Slough is the second largest slough within the Everglades, spanning $409 \mathrm{~km}^{2}$, and extending from the southeastern boundary of ENP, and representing an important surface water connection to the Florida Bay estuary. Together with Shark River Slough, Taylor Slough is a primary focus of studies in the Florida Coastal Everglades Long-Term Ecological Research (FCE LTER) program. The aim of this program is to understand how freshwater delivery interacts with coastal pressures (such as sea level rise and storms) to modify ecosystem processes along these two Everglades flow-ways. The central FCE LTER hypothesis states that improved freshwater delivery will offset and delay the effect of sea level rise on coastal transgression and salinization of the underlying aquifer that supports much of Florida's drinking water (Trexler et al. 2006). Improved freshwater delivery should also promote oligotrophy throughout the system, since freshwater marshes are naturally oligotrophic. This hypothesis is being tested using long-term observational studies (at the time of this publication, over 12 years) along transects that extend from canals at the ENP boundary through the freshwater and coastal wetlands to downstream estuaries. This research is conducted in conjunction with multi-agency collaborative projects that together cover uniquely rich spatial and temporal scales. Projects that are designed to capture the variability driven by natural processes, as well as the effects of engineering efforts aimed at restoring water flow.

Over the last 20 years, attempts to rehydrate the Taylor Slough watershed have changed from point source pumping of surface water from canals to counteract groundwater seepage out of the park, to the regulation of series of surface water retention basins. The goal of these basins is create a hydrologic buffer zone along the Everglades-urban-agricultural boundary by generating diffuse subsurface flow back toward the park. These projects not only have significantly influenced the hydrology of the ENP eastern boundary and the central portion of Taylor Slough, but also affected nutrient loading (Surratt et al. 2012) and non-native and invasive species population introductions. The prospect of successfully restoring both water quantity and quality in Taylor Slough is contingent on understanding the ramification of current and past projects in order to inform and adapt future plans. Here we review the contents of this special issue, geared at synthesizing information from a collection of interdisciplinary studies addressing topics ranging from hydrology to water quality to vegetation and consumer dynamics. Our goal is to link historical ecosystem changes to water management activities in order to better inform and hopefully improve restoration effectiveness.

Hydrologic Changes The special issue begins with a historical review of water management activities affecting Taylor Slough. Through the use of long-term hydrological and 
Fig. 1 Taylor slough and the C-111 basin are located along the eastern boundary of Everglades National Park and southwest of the City of Miami (Florida, USA). Water management projects along the Everglades-Urban-

Agriculture boundary have attempted to control seepage out of this wetland since the 1960s. The greater Everglades watershed includes Everglades National Parks, as well as the water conservations areas (WCAs) and Big Cypress National Preserve to the north (insert)

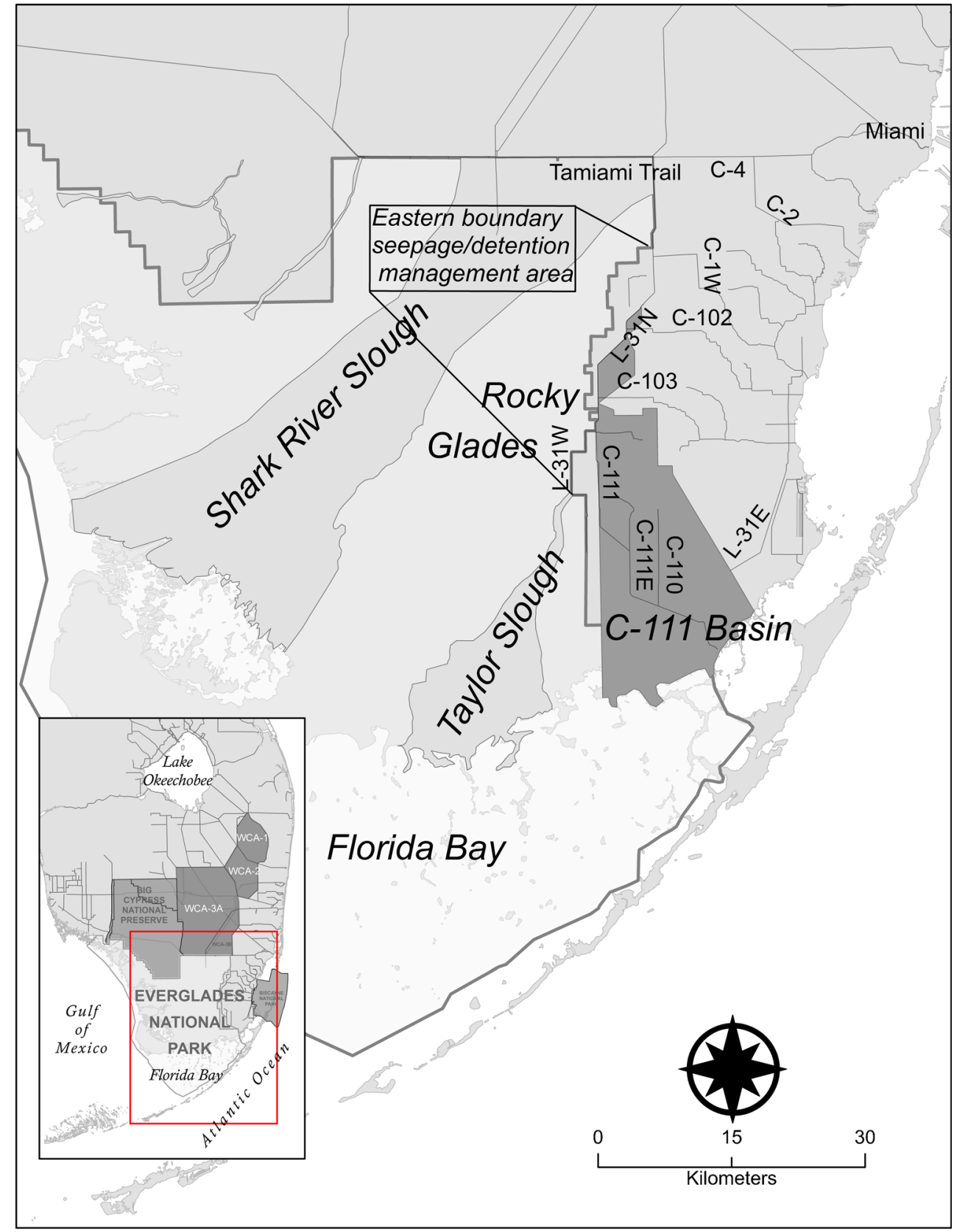

climatological data, Kotun and Renshaw (2014) are able to determine the influence of water delivery projects on water flows and levels to an area that had been effectively disconnected from upstream water sources. Their study shows how water conveyance systems established in the 1960s, together with a subsequent series of pump stations designed to deliver more water across the eastern boundary, succeeded in increasing water flow, water level and duration of inundation in the marsh. However, their findings suggest much of the water reintroduced to the slough moved eastward toward the urbanagricultural boundary instead of downstream through Taylor Slough. This was largely a consequence managing boundary canal stages and discharges to enable adjacent agricultural production and provide flood protection for all developed areas to the east of ENP. Subsequently, the creation and operation of a buffer area between ENP and developed areas, with water detention basins and additional pump stations were designed to reduce this eastward flow (diffuse restoration, 2000-2010), thereby reversing over-drainage of the headwaters. However, improvements appear to be limited to the headwaters of Taylor Slough and may not be influencing downstream salinity or nutrient intrusion. This may be at least partially attributable to relatively low annual and dry season rainfall during this most recent decade. By focusing on this same recent time period, Sullivan et al. (2014) showed that the diffuse restoration approach led to enhanced connectivity 
between surface and groundwater, increasing groundwater discharge to surface waters. The detention basins succeeded in increasing local surface water stage while the continued groundwater seepage toward the urban boundary was concurrent with lower water levels in the western portion of the Taylor Slough headwaters and controlled the downstream delivery of water. Groundwater discharge may improve surface water levels near the Everglades-urban-agricultural boundary, but could constitute a source of constituent loading to the adjacent natural areas.

Biogeochemical Changes To determine trends in nutrient accumulation in soils along the ENP boundaries, Osborne et al. (2014) sampled along transects downstream of three of the canal water inputs to Shark and Taylor Sloughs. They found elevated total phosphorus (TP) concentrations in soils near inflows, particularly in Taylor Slough, frequently exceeded the $500 \mathrm{mg} \mathrm{kg}^{-1}$ threshold that is indicative of $\mathrm{P}$ enrichment in the Everglades. They conclude that the narrow flow path of Taylor Slough may serve to focus canal or groundwater sources of $\mathrm{P}$, relative to the more diffuse flow path in Shark Slough. Taylor Slough also captures P mobilized during the wet season from adjacent short-hydroperiod marsh sediments that oxidize during the dry season. Chambers et al. (2014) report soil nutrient trends over a larger portion of Taylor Slough and adjacent C-111/panhandle basins (Fig. 1). They show that the soil TP concentrations have substantially increased in the freshwater panhandle from 2006 to 2010, possibly related to increased overland flow following removal of levee spoil mounds in 1997 that resulted in increased surface water flow and a shift toward more nutrient rich vegetation (Childers et al. 2006). Results from their factor analysis indicated the spatial variability in soil TP were likely controlled by complex interactions between the source concentrations and delivery, as well as the inherent local characteristics and processes. Variation between sites included the carbonate content of the soils (influencing adsorption), interactions with iron and sulfide, and sequestration in plants, all of which were dependent on water availability. Unfortunately, the absence of pre-operational soil $\mathrm{P}$ data from these areas, along with the fact that spatial variability often exceeds temporal variation, prevents direct conclusions about the interacting influence of water flow and potential P loading alterations on soil properties.

Microbial Community Shifts While Everglades soils typically reflect long-term loading of $\mathrm{P}$ as a result of their ability to retain $\mathrm{P}$, benthic microbial communities can change rapidly upon exposure to novel sources and thus can be used to monitor effects of year-to-year changes in availability. For this reason, benthic microbial communities and their $\mathrm{P}$ content were examined along the ENP boundary (Gaiser et al.
2014). Concentrations of benthic microbial TP in the marsh were elevated near water retention areas and outflows along the ENP boundary. This indicator of nutrient enrichment may be the consequence of the mobilization of legacy $\mathrm{P}$ from adjacent agricultural areas, with transport via surface and groundwater that are both influenced by water management. Notably, the distinctive diatom communities of Everglades periphyton were replaced by weedy, cosmopolitan species in enriched areas, indicating a loss of endemism due to management operations intended to be protective.

Vegetation Responses The effects of water management and soil P changes on Taylor Slough vegetation were examined by Sah et al. (2014), following earlier work to describe vegetation gradients by Armentano et al. (2006). Vegetation in the central slough shifted to wetter communities in the 1980s following establishment of the S-332 pump station that increased water flow and stage, followed by a shift to drier assemblages during the diffuse management period beginning in 2000. Notably, areas in the northern Taylor Slough headwaters shifted to both wetter and higher-P assemblages, indicating an impact of diffuse restoration on both water availability and $\mathrm{P}$ in the area along the northeastern border of ENP. They conclude that plant communities respond in a 3-5 year timeframe of restoration, and when monitored on an annual basis provide a good understanding of general trajectories of change driven by operational shifts. Troxler et al. (2014) investigated the influence of hydrology and salinity on the biomass and production of the two dominant marsh macrophytes, Cladium jamaicense (sawgrass) and Eleocharis cellulosa (spikerush). They noted a shift from sawgrass to spikerush in the central C-111 panhandle and Taylor Slough basin (Fig. 1), but no shift in the headwaters. By extending their sampling into the coastal wetland ecotone, they were able to detect a decrease in sawgrass production due to increased dry season exposure to brackish water, which has not been alleviated by flow management in the upper watershed. Ross et al. (2014) examined whether this coastal transgression is also impacting tree islands, but did not observe a shift to more salt-tolerant species in this distinctive component of the Everglades landscape. Coastal Everglades tree islands appear to be insulated from the short-term effects of salt water intrusion due to their ability to build soils and maintain mesic conditions.

Changes in the Ecotone The reduction of saltwater intrusion in the Taylor Slough oligohaline ecotone by reintroduction of freshwater to the headwaters is a goal of Everglades restoration, and was also explored through long-term water quality analyses and biogeochemical studies. Briceño et al. (2014) examined long-term salinity, nutrient and hydrologic variables in the mangrove ecotone and Florida Bay. Here, they found 
that TP concentrations were positively related to salinity and lowest when discharge values were highest and salinities were lowest, indicating that marine sources continue to be the main supply of $\mathrm{P}$ to the ecotone. They conclude that a $10 \%$ increase in flow, expected to result from the initial CERP project phase for Taylor Slough restoration, would reduce TP concentrations as well as transit time through the estuary. Liu et al. (2014) quantified benthic exchange of $\mathrm{C}, \mathrm{N}$, and $\mathrm{P}$ seasonally in different areas of the Taylor Slough estuarine ecotone and found consistent soil/sediment uptake of dissolved organic $\mathrm{C}$, soluble reactive $\mathrm{P}$, and $\mathrm{NO}_{\mathrm{x}}^{-}$, with consistent release of $\mathrm{NH}_{4}{ }^{+}$. They also showed that Taylor Slough ecotone soils and sediments are rather effective at removing added $\mathrm{P}$ from the water column over relatively short time scales. The capacity of this oligotrophic ecosystem to efficiently cycle and sequester dissolved constituents motivated a study quantifying the transport of flocculent detritus material through the Taylor Slough estuarine ecotone. Koch et al. (2014) examined the influence of hydrology on the transport of particulate organic matter through the estuary using paramagnetic sediment tracers. They discovered that enhanced flows do result in greater downstream loading of detrital material, particularly into the riverine ponds that dominate the estuary-bay confluence. Ramifications of freshwater flows on estuarine food webs as a result of downstream detrital transport should be considered in restoration.

Distribution of Aquatic Consumers Several long-term studies in this issue examine the role of hydrologic and nutrient gradients as drivers of aquatic consumers distribution across the landscape. Throughout the marsh system, Sokol et al. (2014) found that small invertebrates and fish distributions were primarily controlled by seasonal hydrology, while nutrient enrichment influenced their distribution along Everglades-urban-agricultural boundary and near water control structures. Goss et al. (2014) further examined the influence of hydrology on fish community patterns. Here they found that some species, such as eastern mosquitofish (Gambusia holbrooki) and flagfish (Jordanella floridae), disperse quickly after seasonal droughts, while others like the bluefin and least killifish (Luciana goodei, Heterandria formosa, respectively) disperse more slowly. An important strategy for surviving the dry season in Taylor Slough is the ability for fish to find wet depressions, particularly the limestone solution holes that are plentiful in the northern portion of Taylor Slough. While holes that remain hydrated are an important dry season refuge, they tend to favor nonnative over native fishes, particularly invasive predators that consume native species (Rehage et al. 2014). In an area that contains abundant solution holes known as the 'rocky glades' region (Fig. 1), Kline et al. (2014) also showed a high abundance of non-native fishes. Using long-term fish community datasets they demonstrated how water management projects have increased connectivity between the marsh and canal water sources, which was concomitant with increased invasive-exotic species. This research provides evidence that connectivity to boundaries and differential ability to withstand and recover from hydrological disturbances are primary drivers of fish-community structure in the Everglades.

Faunal Shifts The long-term reduction in populations of large vertebrates in the coastal Everglades is perhaps one of the most notable impacts of historic reductions in water flow through the Everglades. Lorenz (2014a) reviewed changes in populations of multiple vertebrate species in the Taylor Slough coastal wetland and northeastern Florida Bay occurring since 1984. He inferred that diversion of freshwater flow away from Taylor Slough resulted in an ecological cascade starting with hydrologic stresses on primary and then secondary producers, culminating in population declines at the top of the food web. Aquatic animal populations are influenced not only by changes in the magnitude of water delivery, but also to the seasonality of water distribution on the landscape. Wading birds are particularly susceptible to changes in prey concentration controlled by water distribution, depth, and timing. For instance, nesting success of Federally protected Roseate Spoonbills (Platalea ajaja) is reduced when hydrologic conditions, including water levels and salinity, reduce prey base production and availability. This production is enhanced by relatively high water and low salinity during the wet season prior to nesting. Prey availability during the dry, nesting season is critical for nesting success and has a non-linear hydrologic relationship, depending on a low water level threshold and an absence of water level reversals (Lorenz 2014b). Lorenz' long-term studies have provided evidence of the influence of changing water management on food web structure, production, and ultimately on a population of charismatic wading birds.

Such changes in the prey base have cascading effects on other top predators, including the American crocodile (Crocodylus acutus). Green et al. (2014) utilized regional hydrologic models to create a stage-based, spatially-explicit population model that predicts the influence of planned restoration activities on the crocodile population. Model predictions indicated that restoration (as laid out in CERP) would result in overall decrease of approximately $3 \%$ in crocodile abundance across south Florida. When examined at the regional level modeling predication indicated a $30 \%$ increase in crocodile abundance in the Taylor Slough/Joe Bay region, which was slightly more offset by decreases in other regions due to stage-based responses of crocodiles to changing salinity. It has been widely recognized that restoration plans must value both magnitude and timing of water delivery, but long- 
term consumer trends and model predictions advise urgency in both implementation and adaptation of these goals to protect and improve Taylor Slough fauna.

\section{Conclusions and Management Implications}

One of greatest challenges facing wetland and riparian managers is the ability to restore or protect both water quantity and quality. Faced with uncertainties regarding the likely efficacy of a given alternative action, scientists play a central role within an adaptive management framework in quantifying and communicating management effects. Unfortunately, quantifying the ecosystem responses to restoration/ management techniques is often compounded by climatic variability, sampling design and lack of long-term data. Here we highlight the successes and lessons learned from a multiagency approach that utilizes uniquely-rich spatial and temporal scales to assess restoration effectiveness.

Tools for Quantifying Restoration Progress Robust and coordinated sample designs, long-term and sustained monitoring, and a suite of models adequate to synthesize knowledge are critical tools to assess indicators of spatial and temporal ecosystem change and guide management decisions (i.e., Doren et al. 2009). Employing a combination of sampling designs is critical for determining ecosystem effects of varying drivers at both large and small temporal and spatial scales. For example, data from repeated, randomized sampling at the landscape scale have shown widespread ecosystem-scale responses to hydrologic management (i.e., Sargeant et al. 2011; Lee et al. 2013), while collections along water flow transects have revealed impacts related to elevated nutrient concentrations at inflow structures (e.g., Gaiser et al. 2014; Osborne et al. 2014; Sah et al. 2014). Spatial designs, including reference areas in Before-After Control-Intervention (BACI) approaches, such as employed by the FCE LTER program (at a large scale, Childers 2006), may be required to determine both patterns and causes of long-term change.

It cannot be overstated that long-term ecological studies at appropriate spatial scales are critical to providing managers with information needed for developing, evaluating, and implementing restoration alternatives as well as assessing the outcomes of restoration (Kotun and Renshaw 2014; Lorenz 2014a, b; Sah et al. 2014). Utilizing long-term datasets is especially critical in order to capture variable climatic conditions, particularly with respect to rainfall quantity, timing, and distribution. For example, over the past decade, the water management strategy for improving Taylor Slough has been to maintain a hydrologic buffer (via surface water detention basins) along the Everglades-urban-agricultural boundary. This strategy succeeded one that directly pumped surface water into the Park for two decades (Kotun and Renshaw
2014). Only through long-term studies could we assess the implementation of the new strategy, which has improved hydrologic conditions in the upper slough. Results from the past decade showed that the new strategy was not effective for restoring downstream hydrologic conditions, but this may have been a consequence of implementing the new management during an extended period of below average rainfall conditions (through 2012). Long-term monitoring will enable us to distinguish the effects of management and long-term climatic variations.

Developing and applying models that link the control of climatic variability on ecohydrologic processes with our evergrowing knowledge of ecosystem properties and species life history traits, is key in order to identify the drivers change at varying temporal and spatial scales. For example, shifts in diatom communities (Gaiser et al. 2014) can be observed in 12 years, providing an early warning of water quality changes, while more long-standing changes in macrophyte distribution and densities are evident in 3-5 years (Sah et al. 2014). Longterm studies of soil chemistry provide an integrated view of how current water management changes must be interpreted in relation to historical practices (Childers et al. 2003). By quantifying the hydro-meteorological drivers of and linkages among these different ecosystem attributes, predictive ecosystem models can be provided (Green et al. 2014) to guide effective scenarios for restoration across temporal and spatial scales. Statistical models are key tools in identifying ecosystem change such as those employed by Sah et al. (2014), Chambers et al. (2014) and Gaiser et al. (2014), but there is a need to merge these results with dynamic models to be able to quantify and predict the influence of restoration on ecosystem recovery.

Coastal Boundary and Restoration Challenges Where the combined effect of sea level rise and decreased freshwater flow has resulted in the encroachment of the saltwater intrusion boundary into the Everglades (Saha et al. 2011), a positive feedback loop may be initiated. Evidence suggests that it is the reduction in water flows to the central Taylor Slough drainage that has increased the rate of mangrove transgression into the ecotone. There is increased urgency to restore flow to the ecotone as saltwater intrusions and resultant ecological transitions, potentially including peat collapse, can occur rapidly. Any topographic loss with peat collapse would likely accelerate saltwater intrusion. Long-term studies of the dynamics of ecotone soils in response to freshwater management have begun and should be a persistent focus of attention.

A recurring theme in this special issue suggests that while an increased quantity of water flowing through the central slough should be a management priority, hydrologic timing is also critical for the ecosystem. Natural cycles of rainfall and runoff throughout the freshwater-marsh mangrove ecotone are 
key attributes that sustain the system's productivity and biodiversity. For example, the contrast between wet and dry season flows in the ecotone are crucial for concentrating prey in a way that makes them accessible to wading birds. The life cycle of these fauna is synchronized with this hydrologic cycle (Goss et al. 2014; Lorenz 2014a). While diffuse water delivery to the upper watershed throughout the wet and dry seasons may improve landscape connectivity (Kotun and Renshaw; Sullivan et al. 2014) and access of small consumers to solution hole refugia (Rehage et al. 2014), the timing of water releases influencing the ecotone must be appropriate to protect nesting and feeding habitat of wading birds, their prey and predators (Lorenz 2014b).

Long-term data suggest that management choices need the flexibility to improve habitat connectivity at the landscape scale as well as the movement and interaction of organisms within food webs (Boucek and Rehage 2013; Goss et al. 2014). Both targets would be met by a management strategy that conveys more freshwater through this system in a manner that mirrors the historical spatial and temporal distribution. While maximizing connectivity within the remaining natural system, management strategies to minimize connectivity with boundary nutrient sources are also being implemented. Effective strategies for regulating the quality of incoming water at levels that protect the marsh ecosystem are well known. Still, meeting the challenge of restoring the ecosystem through improvements in water quantity, timing, and distribution while maintaining quality in an ecosystem where above and below-ground water movement is largely and naturally diffuse remains challenging. However, because long-term trajectories of populations and communities suggest little resilience to rapid colonization by non-native and opportunistic species at the expense of assemblages distinct to the Everglades (Gaiser et al. 2014; Kline et al. 2014; Lorenz 2014a, b; Rehage et al. 2014; Sokol et al. 2014), pressure for rapid implementation of effective solutions grows. Given suggestions that the ecosystem retains resilience and capacity for recovery (Childers et al. 2003; Ross et al. 2014), restoration success is still possible if connectivity-informed strategies are implemented in a timely manner.

\footnotetext{
Acknowledgments This publication was produced as part of a special issue devoted to investigating the ecological response of over 20 years of hydrologic restoration and active management in the Taylor Slough of Everglades National Park. Support for this research was provided by the Department of the Interior's National Park Service through the Everglades Fellowship Program at Florida International University. Support for this special issue was provided by; the Everglades National Park, the Southeast Environmental Research Center, the Florida Coastal Everglades Long-Term Ecological Research program (National Science Foundation cooperative agreement \#DBI-0620409), the Everglades Foundation and the South Florida Water Management District. This is SERC contribution no. 660 .
}

\section{References}

Armentano TV, Sah JP, Ross MS, Jones DT, Coole HC, Smith CS (2006) Rapid responses of vegetation to hydrologic changes in Taylor Slough, Everglades National Park, USA. Hydrobiologia 569:293309

Boucek RE, Rehage JS (2013) No free lunch: displaced marsh consumers regulate a prey subsidy to an estuarine consumer. Oikos. doi:10. 1111/j.1600-0706.2013.20994.x

Briceño H, Miller G, Davis III SE (2014) Relating restored freshwater flow with estuarine water quality in the southern Everglades mangrove ecotone. Wetlands. doi:10.1007/s13157-013-0430-0

Cadenasso ML, Pickett STA, Groffman PM, Band LE, Brush GS, Galvin MF, Grove JM, Hagar G, Marshall V, McGrath BP, O’Neil-Dunne JPM, Stack WP, Troy AR (2008) Exchanges across land-waterscape boundaries in urban systems. The Annals of the New York Academy of Sciences 1134:1749-6632

Chambers R, Hatch RL, Russell TM (2014) Effect of Water Management on Interannual Variation in Bulk Soil Properties from the Eastern Coastal Everglades. Wetlands. doi:10.1007/s13157-013-0393-1

Childers DL (2006) A synthesis of long-term research by the Florida Coastal Everglades LTER program. Hydrobiologia 569:531-544

Childers DL, Doren RF, Noe GB, Rugge M, Scinto LJ (2003) Decadal change in vegetation and soil phosphorus patterns across the Everglades landscape. Journal of Environmental Quality 32:344 362

Childers DL, Iwaniec D, Rondeau D, Rubio G, Verdon E, Madden CJ (2006) Responses of sawgrass and spikerush to variations in hydrologic drivers and salinity in Southern Everglades marshes. Hydrobiologia 569:273-292

Doren RF, Trexler JC, Gottlieb AD, Harwell MC (2009) Ecological indicators for system-wide assessment of the greater everglades ecosystem restoration program. Ecological Indicators 6:S2-S16

Gaiser EE, Sullivan PL, Tobias FAC, Bramburger AJ, Trexler JC (2014) Boundary effects on benthic microbial phosphorus concentrations and diatom beta diversity in a hydrologically -modified, nutrientlimited wetland. Wetlands. doi:10.1007/s13157-013-0379-z

Goss CW, Trexler JC, Loftus WF (2014) Seasonal fish dispersal in ephemeral wetlands of the Florida Everglades. Wetlands. doi:10. 1007/s13157-013-0375-3

Green TW, Slone DH, Swain ED, Cherkiss MS, Lohman M, Mazzotti FJ, Rice KG (2014) Evaluating effects of Everglades restoration on American crocodile populations in South Florida using a spatiallyexplicit, stage-based population model. Wetlands. doi:10.1007/ s13157-012-0370-0

Kline JL, Loftus WF, Kotun K, Trexler JC, Rehage JS, Lorenz JJ, Robinson M (2014) Recent fish introductions into Everglades National Park: an unforeseen consequence of water-management? Wetlands. doi:10.1007/s13157-012-0362-0

Koch G, Hagerthey S, Childers DL, Gaiser EE (2014) Examining seasonally pulsed detrital transport in the coastal Everglades using a sediment tracing technique. Wetlands. doi:10.1007/s13157-0130388-y

Kotun K, Renshaw A (2014) Taylor Slough hydrology, fifty years of water management 1961-2010. Wetlands. doi:10.1007/s13157-0130441-x

Larsen LG, Harvey JW, Crimaldi JP (2007) A delicate balance: ecohydrological feedbacks governing morphology in a lotic peatland. Ecological Monographs 77:591-614

Lee S, Gaiser E, Trexler J (2013) Diatom-based models for inferring hydrology and periphyton abundance in a subtropical karstic wetland: Implications for ecosystem-scale bioassessment. Wetlands 33: $157-173$ 
Liu KJ, Li HP, Davis III SE (2014) Benthic exchange of C, N, and P along the estuarine ecotone of lower Taylor Slough, Florida (USA): Effect of seasonal flows and phosphorus availability. Wetlands. doi:10. 1007/s13157-013-0431-z

Lorenz JJ (2014a) A review of the effects of altered hydrology and salinity on vertebrate fauna and their habitats in Northeastern Florida Bay. Wetlands. doi:10.1007/s13157-013-0377-1

Lorenz JJ (2014b) The relationship between water level, prey availability and reproductive success in Roseate Spoonbills foraging in a seasonally-flooded wetland while nesting in Florida Bay. Wetlands. doi:10.1007/s13157-012-0364-y

Osborne T, Reddy KR, Ellis LR, Aumen N, Surratt D, Zimmerman MS, Sadle J (2014) Evidence of recent phosphorus enrichment in surface soils of Taylor Slough and northeast Everglades National Park. Wetlands. doi:10.1007/s13157-013-0381-5

Palmer MA, Bernhard ES, Allan JD, Lake PS, Alexander G, Brooks S, Carr J, Calyton S, Dahm CN, Follstad Shah J, Galat DL, Loss SG, Goodwin P, Hart DD, Hassett B, Jenkinson R, Kondolf GM, Lave R, Meyer JL, O'Donnell TK, Pagano L, Sudduth E (2005) Standards for ecologically successful river restoration. Journal of Applied Ecology 42: 208-217

Price RM, Swart PK, Fourqurean JW (2006) Coastal groundwater discharge - an additional source of phosphorus for the oligotrophic wetlands of the Everglades. Hydrobiologia 569:23-36

Rehage JS, Liston SE, Dunker KJ, Loftus WF (2014) Fish community responses to the combined effects of decreased hydroperiod and nonnative fish invasions in a karst wetland: are Everglades solution holes sinks for native fishes? Wetlands. doi:10.1007/s13157-0120361-1

Ross MS, Meeder JF, Sah JP, Ruiz PL, Telesnicki GJ (2000) The southeast saline Everglades revisited: 50 years of coastal vegetation dynamics. Journal of Vegetation Science 11:110-112

Ross MS, Sah J, Meeder J, Ruiz P, Telesnicki G (2014) Compositional effects of sea-level rise in a patchy landscape: the dynamics of tree islands in the southeastern coastal Everglade. Wetlands. doi:10. 1007/s13157-013-0376-2
Sah J, Ross MS, Saha S, Minchin P, Sadle J (2014) Trajectories of vegetation response to water management in Taylor Slough, Everglades National Park, Florida. Wetlands. doi:10.1007/s13157013-0390-4

Saha AK, Saha S, Sadle J, Jiang J, Ross MS, Price RM, Sternberg LSLO, Windelberger KS (2011) Sea level rise and South Florida coastal forests. Climate Change 107(1-2):81-108

Sargeant B, Gaiser E, Trexler J (2011) Indirect and direct controls of macroinvertebrates and small fish by abiotic factors and trophic interactions in the Florida Everglades. Freshwater Biology 56: 2334-2346

Sklar FH, Chimney MJ, Newman S, McCormick P, Gawlik D, Miao S, McVoy C, Said W, Newman J, Coronado C, Crozier G, Korvela M, Rutchey K (2005) The ecological-societal underpinnings of Everglades restoration. Frontiers in Ecology and the Environment 3:161-169

Sokol E, Hoch JM, Gaiser EE, Trexler JC (2014) Metacommunity structure along resource and disturbance gradients in Everglades wetlands. Wetlands. doi:10.1007/s13157-013-0413-1

Sullivan PL, Price RM, Schedlbauer JL, Saha A, Gaiser EE (2014) The influence of hydrologic restoration on groundwater-surface water interactions in a karst wetland, the Everglades (FL, USA). Wetlands. doi:10.1007/s13157-013-0451-8

Surratt D, Shinde D, Aumen N (2012) Recent cattail expansion and possible relationships to water management: changes in Upper Taylor Slough (Everglades National Park, Florida, USA). Environmental Management 49:720-733

Trexler J, Gaiser E, Childers D (2006) Interaction of hydrology and nutrients in controlling ecosystem function in oligotrophic coastal environments of South Florida. Hydrobiologia 569:1-2

Troxler TG, Childers DL, Madden CJ (2014) Drivers of decadal-scale change in the structure and function of southern Everglades wetland macrophyte communities. Wetlands. doi:10.1007/s13157-0130446-5

Zedler J (2006) Wetland restoration. In: Batzer DP, Sharitz RR (eds) Ecology of freshwater and estuarine Wetlands. Elsevier, Inc., San Diego, pp 348-406 